\title{
BIOCHEMICAL ASSESSMENT OF IRON PROFILE IN TYPE 2 DIABETES PATIENTS.
}

1. MBBS, DCH, M.Phil (Biochemistry) Senior Lecturer Biochemistry Bannu Medical College, Bannu-KPK 2. MBBS, FCPS

Assistant Professor Medicine KGN Teaching Hospital Bannu-KPK

3. MBBS, FCPS

Associate Professor Gynae and Obs Bannu Medical College, Bannu-KPK

4. MBBS, FCPS

Associate Professor Physiology Bannu Medical College, Bannu-KPK

5. Ph.D (Biotech)

Research Associate Biotechnology UST Bannu-KPK.

Correspondence Address:

Dr. Wasim Ahmad

Research Associate of Biotechnology

UST Bannu-KPK.

vazim4847@gmail.com

Article received on:

02/10/2019

Accepted for publication

04/12/2019
Faridullah Shah', Naseeb Ur Rehman², Zakia Khan ${ }^{3}$, Rafat Ullah', Wasim Ahmad ${ }^{5}$

ABSTRACT... Objectives: Iron profile is considered to be an important guide for improved health around the globe. An altered iron profile is a risk factor for numerous diseases. Extreme iron accretion in body results in damaging many cellular structures as well as in oxidative damage with many complications. Thus, iron profile must be considered in many ailments including DM. Study Design: Descriptive study. Setting: Department of Biochemistry, BMC Bannu and Department of Medicine, KGN Teaching Hospital Bannu-KPK. Period: January 2019 to June 2019. Material \& Methods: 140 subjects were taken in this study, out of which 70 were suffering from type 2 diabetes and 70 were normal healthy controls. BMI was calculated by dividing body weight $(\mathrm{Kg})$ to square of height (meters). The waist / hip circumference ratio was calculated by dividing the waist circumference $(\mathrm{cm})$ to hip circumference $(\mathrm{cm})$. Sphygmomanometer was used for blood pressure measurement. The serum iron, TIBC, UIBC, plasma glucose and HbA1C were measured by semi-auto analyzer. The serum ferritin was estimated by chemiluminescence method. The \% transferrin saturation was calculated by formula serum iron $(\mu \mathrm{g} / \mathrm{dl}) \times 100 /$ TIBC $(\mu \mathrm{g} / \mathrm{dl})$. Result: The anthropometric parameters like weight, BMI, waist circumference, hip circumference, waist hip circumference ratio, systolic and diastolic blood pressure was statistically extremely significantly $(p<0.001)$ increased in type 2 diabetes mellitus subjects as compared to healthy control subjects. The plasma fasting glucose, $\mathrm{HbA1C}$, serum iron, \% saturation and serum ferritin were statistically extremely significantly $(p<0.001)$ increased and UIBC was statistically extremely significantly $(p<0.001)$ decreased while TIBC and hemoglobin were statistically significantly $(p<0.05)$ decreased in type 2 diabetes mellitus subjects as compared to healthy control subjects. Conclusion: Elevated iron and ferritin is a risk factor for diabetes and produce many complications. Proper management must be taken to remove the excess iron that can be very harmful to the body."

Key words: $\quad$ Anthropometric Parameter, Diabetes Mellitus, Fasting Blood Glucose, Ferritin, Iron.

Article Citation: Shah FU, Naseeb Ur Rehman, Khan Z, Rafat Ullah, Ahmad W. Biochemical assessment of iron profile in type 2 diabetes patients. Professional Med J 2020; 27(8):1590-1594. DOI: 10.29309/TPMJ/2020.27.08.4212

\section{INTRODUCTION}

Diabetes Mellitus is a disorder which has a no of hazardous effects on human health. ${ }^{1}$ In Asia, particularly in south east region, the no of victims having DM were 72million in the year 2013 and an estimation is there that sates its no 123 million by the year $2035 .^{2}$ The incidence of the disease is on the move in south Asian countries and the reason is higher genetic predilection, higher $\mathrm{BMI}$ of the inhabitants of the area, higher insulin resistance and various environmental factors. ${ }^{3}$ More or less, all types of DM are associated with insulin deficiency as well as $\mathrm{CHO}$, protein and lipid metabolism disturbances. ${ }^{4}$
In DM, chronic hyperglycemic condition is generally linked with damage which is shown to be long term, and various organs including heart, kidneys, nerves and eyes dysfunction and failure. ${ }^{5}$ it is to be noted that due to its metabolic nature, the victims of the disease might experience other associated complications as well. A no of changes in the human body are resulted due to an elevated blood glucose level that affects, in turn, almost every part of the body. The DM patient is supposed to develop many micro and macro-vascular complications including stroke and atherosclerosis. ${ }^{6} \mathrm{~A}$ newer term, dyslipidemia has replaced the older one, hyperlipidemia 
which means lipid profile's abnormal alterations. Dyslipidemia involves alteration in HDL cholesterol, LDL cholesterol, triglycerides and VLDL cholesterol. As for as diabetic dyslipidemia is concerned, it embraces reduced $\mathrm{HDL}$ cholesterol, elevated TG (triglycerides) and an excess of LDL cholesterol. ${ }^{7}$ The DM is associated with predominant lipid abnormalities due to insulin deficiency or its resistance that in turn results in affecting enzymes functions. ${ }^{8}$

As a co-factor, iron plays an important role for transport of electron and oxidation of fuel. It can result in an oxidative damage if not regulated with care. The main objective of this study was to assess the biochemical assessment of iron profile in type 2 diabetic patients reported to KGN teaching hospital Bannu-KPK in addition to a comparative study of anthropometric markers in comparison to control subjects.

\section{MATERIAL \& METHODS}

This research study, which is a descriptive study, was a combined work carried out at the Department of Biochemistry, BMC Bannu and Department of Medicine, KGN teaching hospital Bannu-KPK from January 2019 to June 2019. The study was approved by the ethical committee of the BMC Bannu.

The study was conducted on 140 patients out of which 70 were healthy controlled subjects and 70 were diagnosed with type 2 DM. Cohen's D test was applied to calculate the sample size. Clinical background/history of all the subjects were recorded in study proforma. Inclusion criteria for the study was type 2 DM subjects with fasting blood glucose level $\geq 127 \mathrm{mg} / \mathrm{dl}$. All the subjects who had genetic mutation, were taking drugs that disturbed iron metabolism and conceived female were excluded from the study.

Anthropometric markers/parameters measurement was done as in the following:

$\mathrm{BMI}$ of the patients was calculated by using body fat and hydration electronic calculator. The hip/ waist circumference ratio was measured by using measuring tape. The blood pressure was calculated using mercury sphygmomanometer.
Fasting blood $(5 \mathrm{ml})$ was collected from the subjects under study. The collection tubes were incubated for a time period of $20 \mathrm{~min}$ at a temperature $37^{\circ} \mathrm{C}$. After incubation time, blood clot was removed, and the samples were centrifuged at 3000 rpm for 15 to 20 minutes. Soon after centrifugation, the supernatant was collected and reserved for biochemical profile and tests. The following biochemical tests were performed for the desired objective.

TIBC (total iron binding capacity), UIBC (unsaturated iron binding capacity), serum iron, and plasma glucose using bio-analyzer. Hba1c and serum ferritin were also calculated.

The data was analyzed using SPSS version 24 . Cohen's d test was applied for assessing the sample size. $Z$ test was used for the assessment of biochemical and anthropometric parameters. Graphs were made using Graph pad prism 5.

\section{RESULTS}

The results of our finding revealed a significant increase in anthropometric parameters (BMI, weight, hip circumference, waist circumference and their ratio, diastolic and systolic blood pressure etc.) in the patients suffering from type 2 diabetes. This increase was found to be highly significant $(p<0.001)$ as compared to control subjects. The results are briefly shown in Table-I below. It was evident from our findings that the level of $\mathrm{HbA} 1 \mathrm{c}$, fasting blood glucose, percent saturation, serum ferritin and serum iron were increased significantly. The values were found to be highly significant $(p<0.001)$. The levels of UIBC were decreased which were found to be highly significant $(p<0.001)$. The decrease in hemoglobin and TIBC levels was found to be decreased $(p<0.05)$ in patients suffering from type $2 \mathrm{DM}$ as compared to control subjects. The results are shown in Table-II below. 


\begin{tabular}{|c|c|c|c|c|c|c|c|c|c|}
\hline Groups & & $\begin{array}{l}\text { Height } \\
\text { (meter) }\end{array}$ & $\begin{array}{c}\text { Weight } \\
\text { (kg) }\end{array}$ & $\begin{array}{c}\text { BMI } \\
\left(\mathrm{kg} / \mathrm{m}^{2}\right)\end{array}$ & $\begin{array}{c}\text { Waist } \\
\text { (cm) }\end{array}$ & $\begin{array}{l}\text { Hip } \\
(\mathrm{cm})\end{array}$ & $\begin{array}{l}\mathrm{W} / \mathrm{H} \\
\text { ratio }\end{array}$ & $\begin{array}{l}\text { Diastolic } \\
(\mathrm{mm} / \mathrm{Hg})\end{array}$ & $\begin{array}{c}\text { Systolic } \\
(\mathrm{mm} / \mathrm{Hg})\end{array}$ \\
\hline \multirow{3}{*}{$\begin{array}{l}\text { Control } \\
\text { subjects } \\
n=70\end{array}$} & Min & 1.42 & 50 & 20.20 & 68.22 & 82.44 & 0.82 & 78 & 124 \\
\hline & Mean & 1.54 & 57.5 & 21.95 & 74.16 & 90.71 & 0.81 & 82 & 134 \\
\hline & $\pm \mathrm{SD}$ & 0.04 & 2.28 & 1.00 & 2.10 & 2.65 & 0.02 & 2.32 & 1.88 \\
\hline \multirow{3}{*}{$\begin{array}{l}\text { Type } \\
2 \text { DM } \\
\text { subjects } \\
n=70\end{array}$} & Max & 1.64 & $88^{* *}$ & $31.34^{\star *}$ & 98.42 & 99.56 & 0.98 & 92 & 138 \\
\hline & Mean & 1.43 & 72 & 26.72 & 87.81 & 92.88 & 0.93 & 88 & 128 \\
\hline & $\pm \mathrm{SD}$ & $0.02 * \star \star$ & 4.44 & $2.46^{\star \star \star}$ & $3.24 * \star \star$ & $2.98 * \star \star$ & $0.06 * * *$ & $4.10 * \star \star$ & $2.88^{\star \star \star}$ \\
\hline
\end{tabular}

\begin{tabular}{|c|c|c|c|}
\hline No & Biochemcial Parameters & Control & Type 2 Diabetic Patients \\
\hline 1 & FBS (mg/dl) & $90 \pm 4$ & $220 \pm 2$ \\
\hline 2 & HbA1c (\%) & $8 \pm 1$ & $22 \pm 2$ \\
\hline 3 & TIBC (microgm/dl) & $280 \pm 8$ & $255 \pm 6$ \\
\hline 4 & UIBC (microgram/dl) & $220 \pm 8$ & $180 \pm 5$ \\
\hline 5 & Iron (microgm/dl) & $110 \pm 4$ & $140 \pm 6$ \\
\hline 6 & Saturation (\%) & $40 \pm 2$ & $52 \pm 2$ \\
\hline 7 & Ferritin (ng/ml) & $220 \pm 6$ & $360 \pm 8$ \\
\hline
\end{tabular}

\section{DISCUSSION}

The results of this study showed an increase in anthropometric parameters including BMI, weight, height and their ration, waist and hip circumference and both diastolic, systolic blood pressure in type $2 \mathrm{DM}$ patients in comparison to those normal subjects. The matched results were found by some other investigators as well. ${ }^{9-15} \mathrm{We}$ found a decrease in TBIC, $\mathrm{Hb}$ and UBIC whereas an increase was noticed in \% saturation, $\mathrm{HbA1c}$, serum iron and fasting blood glucose levels. Our results were consistent with the work done and results found by some other researchers. ${ }^{16-20} \mathrm{~A}$ closer association is there in type $2 \mathrm{DM}$ and iron profile and this is because an alteration in blood glucose metabolism can results in altered iron metabolism and so on.

A report showed a negative relationship between serumferritin concentrationand insulin sensitivity. ${ }^{21}$ This report shows a closer association between total body Fe stores and insulin resistance. It is evident from various studies that obesity is a risk factor for type 2 DM. ${ }^{22-25}$
Fats are accumulated in the tissues and cells. These cells, in turn, produces certain chemicals that might results in the initiation of inflammatory processes. ${ }^{26-28}$ Many other processes are negatively influenced in hyperglycemic states that in turn, affects iron metabolism. ${ }^{29}$ Various reports around the globe demonstrated iron overload in the patients suffering from type 2 diabetes. ${ }^{30-32}$ Via Haber-Weiss and Fenton reactions, the free iron radicals initiate oxidation of biomolecules leading to generation of hydroxyl radical $\left(\mathrm{OH}^{*}\right)$. These radicals damage cellular membrane protein and nucleic acid. These events lead to insulin resistance and finally type 2 diabetes mellitus. ${ }^{33}$ The free $\mathrm{OH}^{*}$ causes nonenzymatic glycation of protein. The non-enzymatic glvcation of proteins followed by a series of reactions and rearrangements resulting in the formation of advanced glycation end products (AGEs). These mechanisms, together with the interaction of the AGEs with their receptors (RAGE), induce ROS production. The Glycated transferrin has decreased ability to bind $\mathrm{Fe} 3+$ and thus induces the pool of free iron. The free iron and oxidative 
stress also promote the synthesis of ferritin. ${ }^{34}$

\section{CONCLUSION}

It is concluded form the above research work that assessment of iron profile in patients suffering from type 2 DM might be a useful tool. An enhanced level of ferritin and iron are the risk factors for DM that can results in the development of a no of serious complications. In order to remove the excess iron from the body that might be a threat for the life, proper steps should be taken.

\section{Copyright@ 04 Dec, 2019.}

\section{REFERENCES}

1. Sharma S, Sharma AK, Singh AK, Kumar M, Tripathi N. Biochemical profile in type 2 diabetes mellitus with special reference to dyslipidemia: $A$ retrospective study. Int J Med Sci Curr Res 2018; 1 (2):27-34.

2. Thagele SN, Sharma AK, Singh N, Kumar M, Rawat D, Sharma S. Impact of disease duration on lipid profile in type 2 diabetes mellitus patients. J Med Sci Clin Res (JMSCR) 2018; 9(3):697-701.

3. International diabetes federation. IDF Diabetic Atlas 8th Edition 2017. Available from: https://www.idf.org/ elibrary/epidemiology-research/diabetes-atlas. [Accessed 20 September 2018].

4. Papatheodorou K, Papanas N, Banach M, Papazoglou D, Edmonds M. Complications of Diabetes 2016. Journal of Diabetes Research. 2016; 2016:6989453. doi:10.1155/2016/6989453.

5. Lobo V, Patil A, Phatak A, Chandra N. Free radicals, antioxidants and functional foods: Impact on human health. Pharmacognosy Reviews. 2010; 4(8):118-126. doi:10.4103/0973-7847.70902.

6. Clifford J, Niebaum K, Bellows L. Iron: An Essential Nutrient - 9.356. Available from: http://extension. colostate.edu/topicareas/nutrition-food-safetyhealth/iron-an-essential nutrient-9- 356/. [Accessed 20 September 2018].

7. Tandara L, Salamunic I. Iron metabolism: Current facts and future decisions. Biochemia Medica 2012; 22(3):311-328. http://dx.doi.org/10.11613/BM.2012.034.

8. Sen S, Ghatak SK, Majumdar D, Sen K, Bhattacharya B. Free iron status \& insulin resistance in type 2 diabetes mellitus: Analyzing the probable role of a peanut protein. Indian J Med Res 2015; 142(5):606609. doi:10.4103/0971-5916.171291.
9. Simcox JA, McClain DA. Iron and diabetes risk. Cell Metab 2013; 17(3):329-341. doi:10.1016/j. cmet.2013.02.007.

10. Huang J, Jones D, Luo B. Iron overload and diabetes risk: A shift from glucose to fatty acid oxidation and increased hepatic glucose production in a mouse model of hereditary hemochromatosis. Diabetes 2011; 60(1):80-87. doi:10.2337/db10-0593.

11. Karnchanasorn R, Huang J, Ou H-Y. Comparison of the current diagnostic criterion of $\mathrm{HbA1} \mathrm{c}$ with fasting and 2- Hour plasma glucose concentration. J Diabetes Res 2016; 2016:6195494. doi:10.1155/2016/6195494.

12. Kim BJ, Ahn SE, Bae SJ, Kim EH, Lee SH, Kim HK. Iron overload accelerates bone loss in healthy postmenopausal women and middle-aged men: A 3-year retrospective longitudinal study. J Bone Miner Res 2012; 27(11): 2279-2290. DOI:10.1002/jbmr.1692.

13. Gokhale VS, Jagdale N, Batra T, Gulati S. A study of waist circumference, waist-hip ratio as markers of type 2 diabetes mellitus and their correlation with family history of diabetes. Int J Res Med Sci 2017; 5:70-74.

14. Sushil MI, Muneshwar J, Khan MS. To study body mass index, waist circumference, waist hip ratio, body adiposity index and lipid profile level in patients with type-2 diabetes mellitus. IOSR J Dent Med Sci 2015; 1(14):98-101.

15. Haghighatdoost F, Amini M, Feizi A, Iraj B. Are body mass index and waist circumference significant predictors of diabetes and prediabetes risk: Results from a population based cohort study? World J Diabetes 2017; 8(7):365-373. doi: 10.4239/wjd. v8.i7.365.

16. Grossman A, Grossman E. Blood pressure control in type 2 diabetic patients. Cardiovasc Diabetol 2017; 16:3. doi:10.1186/s12933-016-0485-3.

17. Kaleab Tadesse $\mathrm{K}$, Hiwot Amare $\mathrm{H}$, Tesfahun Hailemariam T, Tewodros Gebremariam T. Prevalence of hypertension among patients with type 2 diabetes mellitus and its socio demographic factors in Nigist Ellen Mohamed Memorial Hospital Hosanna, Southern Ethiopia. J Diabetes Metab 2018, 9(4):792. doi: 10.4172/2155-6156.1000792.

18. Misra G, Bhatter SK, Kumar A, Gupta V, Khan MY. Iron Profile and glycaemic control in patients with type 2 diabetes mellitus. Santulli G, ed. Med Sci 2016; 4(4):22. doi:10.3390/medsci4040022.

19. Kapoor S, Sharma AK. Study of serum parameters of iron metabolism in type 2 diabetes mellitus patients. J Chem Pharm Res 2015; 7(3):1839-1844. 
20. AL-Mohammad HMK, Jawad MM, Ali F, Hussan F. Role Iron in Diabetes mellitus type 2 of the patients in province Diwaniya. Al-Kindy College Med J 2017; 1:6365.

21. Borah M, Goswami RK. Evaluation of serum ferritin in in type II diabetes mellitus: a hospital based observational study from Dibrugarh, Assam, India. Int J Res Med Sci 2016; 4:4916-4921.

22. Fernandez-Real JM, Lopez-Bermejo A, Ricart W. Crosstalk between iron metabolism and diabetes. Diabetes 2002; 51:2348-2354.

23. Manikandan A., Ganesh M, Silambanan, S. Study of iron status in type 2 Diabetes Mellitus. Int $\mathrm{J}$ Clin Biochem Res IJCBR 2015; 2:77-82.

24. Huang J, Karnchanasorn R, Ou H-Y. Association of insulin resistance with serum ferritin and aminotransferases-iron hypothesis. World J Exp Med 2015; 5(4):232-243. doi:10.5493/wjem.v5.i4.232.

25. Monteiro SCM, Belfort IKP, Fernandes MA, Sousa WR, Araújo MFMD. Association between serum ferritin levels and insulin resistance in nondiabetic Brazilians. Int Arch Med Sec: Endocrinol 2016; 9(172). doi: $10.3823 / 2043$.

26. WebMD. Diabetes and Inflammation. Available from: https://www.webmd.com/diabetes/type-2diabetesguide/inflammation-and-diabetes\#1

27. Arman $Y$, Ugurlukisi B, Yuruyen G, Akarsu M, Kose M, $\mathrm{Cil} E \mathrm{E}$ et al. The effect of blood glucose regulation on ironmetabolism and hepcidin in uncontrolled type 2 diabetic patients. Int J Clin Exp Med 2016; 9(2):386976.
28. Huang J, Jones D, Luo B, et al. Iron overload and diabetes risk: A shift from glucose to fatty acid oxidation and increased hepatic glucose production in a mouse model of hereditary hemochromatosis. Diabetes 2011; 60(1):80-87. doi:10.2337/db10-0593.

29. Wang $H$, Li $H$, Jiang $X$, Shi W, Shen $Z$ and Li $M$. Hepcidin is directly regulated by insulin and plays an important role in iron overload in streptozotocininduced diabetic rats. Diabetes 2014; 63:1506-1518.

30. Barton JC, Acton RT. Diabetes in HFE hemochromatosis. JDiabetes Res 2017; 2017:9826930. doi:10.1155/2017/9826930.

31. Misra G, Bhatter SK, Kumar A, Gupta V, Khan MY. Iron profile and glycaemic control in patients with type 2 diabetes mellitus. Santulli G, ed. Med Sci 2016; 4(4):22. doi:10.3390/medsci4040022.

32. Preedy VR. Diabetes: Oxidative stress and dietary antioxidants elsevier science; 2013. Available from:// books.google.co.in/books?id=s8vGngEACAAJ.

33. Tabish SA. Is Diabetes becoming the biggest epidemic of the twenty-first century? International Journal of Health Sciences. 2007; 1(2):V-VIII.

34. Ramachandran A, Snehalatha C, Ma RC. Diabetes in South-East Asia: An update. Diabetes Res Clin Pract. 2014, 103: 231-7. 10.1016/j.diabres.2013.11.011.

\begin{tabular}{|l|l|l|l|}
\hline \multicolumn{3}{|c}{ AUTHORSHIP AND CONTRIBUTION DECLARATION } \\
\hline Sr. \# & \multicolumn{1}{|c|}{ Author(s) Full Name } & Contribution to the paper & Author(s) Signature \\
\hline 1 & Faridullah Shah & 1st Author \\
\hline 2 & Naseeb Ur Rehman & 2nd AUthor \\
\hline 3 & Zakia Khan & 3rd Author \\
\hline 5 & Rafat Ullah & Wth Author \\
\hline 5 & Wasim Ahmad & 5th Author
\end{tabular}

